\title{
Exploring knowledge management within teams from a social capital perspective: a literature review
}

\section{Explorando a gestão do conhecimento dentro de times sob a ótica do capital social: uma revisão de literatura}

\author{
Rosangela Fritscher Santos ${ }^{1}$, Gabriela Bragagnolo ${ }^{1}$, Mirian Oliveira ${ }^{1,2}$ (드, \\ Marcírio Silveira Chaves ${ }^{1}$ \\ ${ }^{1}$ Pontifícia Universidade Católica do Rio Grande do Sul - PUCRS, Porto Alegre, RS, Brasil. \\ E-mail: rosangela.fritscher@acad.pucrs.br; gabriela.bragagnolo@acad.pucrs.br; miriano@pucrs.br; \\ marcirio.chaves@pucrs.br \\ 2Universidade de Lisboa, Centro de Investigação Avançada em Gestão/Investigação em Ciências Sociais e Gestão, \\ Instituto Superior de Economia e Gestão, Lisboa, Portugal.
}

How to cite: Santos, R. F., Bragagnolo, G., Oliveira, M., \& Chaves, M. S. (2020). Exploring knowledge management within teams from a social capital perspective: a literature review. Gestão \& Produção, 27(2), e4907. https://doi.org/10.1590/0104-530X4907-19

\begin{abstract}
We live in an economy based on knowledge where the socialization that takes place through relation networks is the key in the construction of this knowledge. The aim of this research is to explore the state of the art of Knowledge Management in teams inside organizations and in conjunction with the theory of Social Capital. To achieve the proposed aim, a systematic review of literature, using thirty three articles - thirty with empirical research and three theoretical articles - was carried out. The academic contribution is the understanding of the operation of Social Capital and Knowledge Management in teams that make use of agile methods in carrying out work. The technical contributions for team and project managers are presented through consolidation of factors that were identified or supported by the research as influencing performance, learning, and improvement of processes, among others.
\end{abstract}

Keywords: Social capital; Knowledge management; Agile methods; Teams.

Resumo: Vive-se numa economia baseada no conhecimento onde a socialização que acontece através das redes de relacionamento é chave na construção desse conhecimento. $O$ objetivo desta pesquisa é explorar o estado da arte sobre Gestão do Conhecimento em times dentro das organizações e em conjunto com a teoria do Capital Social. Para atingir o objetivo proposto, foi realizada uma revisão sistemática de literatura com trinta e três artigos - trinta com pesquisa empírica e três artigos teóricos. A contribuição acadêmica se dá principalmente pela identificação de oportunidade de pesquisas futuras relacionada ao entendimento da atuação do Capital Social e Gestão de Conhecimento em times que utilizam métodos ágeis para execução do trabalho. As contribuições técnicas para gestores de time e de projetos são apresentadas por meio da consolidação de fatores que foram identificados ou suportados pelas pesquisas como influenciadores da performance, aprendizado e melhoria de processos entre outros.

Palavras-chave: Capital social; Gestão do conhecimento; Métodos ágeis; Times.

Received June 6, 2018 - Accepted Sept. 15, 2018

Financial support: Fundação para a Ciência e a Tecnologia UIDB/04521/2020.

This is an Open Access article distributed under the terms of the Creative Commons Attribution License, which permits unrestricted use, distribution, and reproduction in any medium, provided the original work is properly cited. 


\section{Introduction}

In the 1990s, with the growth in the economy based on knowledge, the need arose on the part of executives pay more attention to the knowledge existing in organizations and understand in what way it was used to support business (Hansen et al., 1999). This context stimulated the creation of the discipline of Knowledge Management (KM) in the mid- 1990s (Serenko, 2013). The mobilization of knowledge becomes necessary to support the strategy of organizations and the importance of $\mathrm{KM}$, when a tool to reach the desired competitive advantage, is a fact consolidated in literature (Gonzalez \& Martins, 2017).

The literature on KM indicates that its effective management in organizations brings such benefits as: organizational learning, performance improvement, the creation of competitive advantage, innovation and continuous improvement of processes (Davenport \& Prusak, 1998; Lee, 2001; Karkoulian et al., 2010). The results of KM can also be intangible; a growing valuation of the intangible patrimony of organizations since the end of the last century, through the substantial differences between the market value and the book value attributed to companies (Carvalho \& Gomes, 2017).

In turn, the theory of Social Capital has in its essence the relational networks whose capital - whether knowledge or other type of capital - is fed by social relations (Bourdieu, 1986). The idea that competitive advantage can be obtained through organizations that collaborate in knowledge networks has been recognized as a promising business strategy (Walker \& Christenson, 2005). Social Capital is an important mechanism in giving individuals access to crucial resources available in other people, exercising a fundamental role as an influencing factor in the behavior and attitudes of the members of organizations in relation to the sharing of tacit knowledge (Isa et al., 2010). Social Capital is also considered essential to solve complex or unknown problems, both for young and more mature teams (Šmite et al., 2017).

This article aims to analyze, through a systematic review of literature, the state of the art of research related to the theory of Social Capital with Knowledge Management in the ambit of teams. This joint study is relevant because the current economy is very much supported in knowledge and this is socialized by relational networks (the essence of social capital); adding to this, the theory of Social Capital is among the most used theories in research on KM (Xavier et al., 2012; Wang \& Noe, 2010). This study also extends the context of analysis to teams that work with agile methods. Such methods are supported in tacit knowledge and have expanded to different industries through the need for agility and dynamism on the part of organizations (Serrador \& Pinto, 2015).

The results of this literature review allow researchers to identify what has already been researched in relation to these themes and to identify opportunities for future research in the areas of KM and Social Capital. In addition, knowledge managers can benefit from this study through the identification of factors that would positively influence the results, thus being able to make a critical analysis and adapt them to their context. Results not supported by the research can also be useful for managers, facilitating a possible correction of strategy.

This introduction is followed by the section on theoretical foundation, which presents the key concepts of this study. Then come the methodological procedures used to achieve the aim. Section 4 - Analysis of Articles - presents different information referring to the articles studied as well as the analysis of this information. Then, section 5 presents the discussion based on the analysis and the literature. Finally, the conclusion of the article, exposing the limitations and opportunities for future research. 


\section{Theoretical basis}

This section presents concepts on the theory of Social Capital and KM. The theory of Social Capital is among the four theories most associated with research on KM (Xavier et al., 2012). The fact that these two concepts are treated in conjunction emphasizes the importance of tacit knowledge as inherent to $\mathrm{KM}$, with this requiring social interaction between members of a team, approached by the theory of Social Capital, to then become public knowledge (Robert et al., 2008). In addition, in this section the concepts of Team and their approach in this work are described, along with the concept of Agile Methods.

\subsection{Social capital}

The Social Capital theory originates from Sociology and has been frequently used to study non-organizational phenomenona and more recently, late 1990's, also organizational phenomenona. In terms of non-organizationl phenomena, some example are researches related to social behaviors and civic engagement; and from organizational side, subjects like professional development, ability to find a job and resource sharing (Alguezaui \& Filieri, 2010).

The theory of Social Capital resides in relational networks, whose capital - whether knowledge or another type of capital - is fed by social relations, giving members of the network the collective ownership of the capital and a credential to use it in different means and situations (Bourdieu, 1986).

Social Capital is formed by diverse components that share two common characteristics: they all have some aspect of social structure and facilitate actions of individuals who are part of this structure (Coleman, 1994). Nahapiet and Ghoshal built on Coleman's studies and introduced Social Capital theory into Business and Management fields during the 1990's (Filieri \& Alguezaui, 2014) suggesting that the two characteristics pointed out by Coleman facilitate the development of intellectual capital, as they impact the conditions necessary for the exchange and combining of resources to occur (Nahapiet \& Ghoshal, 1998).

Conditions need to be satisfied for the exchange and combining of resources to actually occur; these conditions are the existence of: opportunity; the expectation of creating value through interaction between parts; motivation or incentive and the ability to combine information or experience (Nahapiet \& Ghoshal, 1998). The impact of these conditions occurs through the three dimensions of Social Capital (Nahapiet \& Ghoshal, 1998):

- Structural: represents the linkages between people and groups. These networks are configured in terms of density, connectivity and hierarchy;

- Cognitive: refers to the resources that have representation, interpretation and systems of meaning shared among the parties, for example language, codes and narratives;

- Relational: refers to resources or assets created through relationships and behavior between individuals. Its main facets are trust and trustworthiness, obligations and expectations, norms and sanctions, identity and identification.

The focus of Social Capital theory in this article is organizational, and it has naturally emerged from the key words used in the selection of papers to be part of this study, as can be seen in section 3.2. 


\subsection{Knowledge management}

The roots of KM go back thousands of years, with the documented work of Plato in 339 AD. He tried to define and conceptualize knowledge (Serenko, 2013). The questions relative to the preservation, utilization and sharing of knowledge have been developed throughout history, though $\mathrm{KM}$ as a scientific discipline is young, dating from the 1990s (Hansen et al., 1999).

Knowledge has been classified into two types: tacit - that which is in the head of the individual, and explicit - that which is documented (Nonaka \& Konno, 1998). In other words, tacit knowledge is an individual's know how and is more difficult to transmit, while explicit knowledge (know what) is more easily communicated and transferred. Tacit knowledge can give organizations competitive advantages when managed effectively, since it is not easily imitated (Polanyi, 1966; Nonaka, 1994).

In the 1990s, with the growth in the economy based on knowledge, executives began to concern themselves with examining knowledge that existed in their companies and how it was used to support business. Allied to the growing dissemination of computers connected in networks, the following strategies for managing this knowledge then appeared (Hansen et al., 1999):

- Codification: characterized by the people-to-documents approach, which involves the codification of knowledge through data bank storage, where it can be easily accessed and used by other people;

- Personalization: characterized by the person-to-person approach, where the role of the computer is to help in the communication of knowledge, and not its storage

$\mathrm{KM}$ is treated as a group of processes. Some differences appear in the literature in relation to the number or name of the processes, but not in relation to their concepts. Alavi \& Leidner (2001) present KM as divided into four main processes, which are: creation, storage, sharing and use. These processes can be sub-divided into creating knowledge internally and acquiring it externally; storage on documents versus storage in routines as well as sharing knowledge internally or externally in the dimensions of individuals, groups and organizations (Alavi \& Leidner, 2001; Lee, 2001; Anand \& Singh, 2011).

The knowledge spiral, represented through the SECl model, is based on the presuppositions that knowledge is created through the conversion of tacit knowledge into explicit knowledge, or vice-versa. According to Nonaka (1994), the SECl model covers four modes of conversion, which are:

- Socialization: aims at the sharing of experience between individuals;

- Externalization: is the conversion of tacit knowledge into explicit knowledge through the stage of externalizing the process of interaction;

- Combination: joins different forms of explicit knowledge of individuals through exchange mechanisms, such as meetings, for example.

- Internalization: is the conversion of explicit knowledge into tacit knowledge through the stage of internalizing, which can be compared to the concept of learning.

The Socialization mode is the key stage in the creation of knowledge, for as people interact and share tips, techniques and narratives, they absorb and apply this shared knowledge, generating new knowledge (Nonaka \& Takeuchi, 1995; Walker \& Christenson, 2005). 


\subsection{Teams}

The literature presents different terminologies and concepts to identify people who work together, varying from groups, work groups and teams. Groups and teams are defined by five attributes: size, objective, interdependence of members, structure and identity (Keyton \& Beck, 2008). The distinction of the term 'team' comes about from the fact that, besides the members having a shared vision of the group's objectives, the team develops a structure to achieve common objectives (Wheelan \& Hochberger, 1996). Teams are also defined as groups that can achieve positive results through the co-operative efforts of the people who compose them, with the impact of the team being greater than the sum of each individual effort (Xiang et al., 2013).

Such attributes as 'temporal' and 'geographical location' are also found in the literature when referring to teams. Temporal duration is specified by Devine et al. (1999) as temporary, short term and long term. The attribute of 'geographical location' is very relevant due to the functional dynamic that it generates in teams. As for geographical distribution, teams can be co-located: a situation in which the team members are physically close; offshore: when team members are not physically close, being in other cities or countries (Sidhu \& Volberda, 2011) - and virtual teams - those characterized by groups of individuals that have a mutual dependency but who work distributed in space, time and organizational frontiers and communicate with each other through technological tools (Hambley et al., 2007).

\subsection{Agile methods}

In the organizational context, agility involves identifying and responding quickly to changes and being faster in delivering results. The processes or agile methods used in the team context suggest informal communication rather than written documentation, giving emphasis to tacit knowledge rather than explicit knowledge (Ryan \& O'Connor, 2013).

Agile methods of software development appeared in the late 1990s as a response to the challenges of the software industry, which had frequently been labeled as inflexible and incapable of absorbing changes. In the context of software development, the definition of agility is characterized by the flexibility of quickly creating and absorbing changes, learning from change and adding value to the customer through the relationship with the environment (Conboy, 2009; Yu \& Petter, 2014).

The use of agile methods has been expanding to other areas, beyond the software industry. Their adoption and popularity have been growing, according to data presented in research by Serrador \& Pinto (2015), in other industries such as construction, education, government, financial services, health, hi-tech, telecommunications, manufacturing, among others. This has occurred because these industries also need solutions to facilitate the absorption of deviations in planning.

\subsection{Knowledge management in teams from a social capital viewpoint}

This research analyzes the influence of Social Capital, through its Structural, Relational and Cognitive dimensions, in KM processes, that is, creation, storage, sharing and use of knowledge. The analysis context is teams within organizations, with the observation of the characteristics of geographical location, co-located teams (people who work physically close) or distributed teams (people who work in geographically dispersed locations, including virtual teams), which make use of agile methods. 


\section{Method}

This section is structured in two parts: Method Classification, and Data collection and Analysis.

\subsection{Method classification}

The method used was a systematic review of the literature on how the theory of Social Capital and KM are approached in the context of teams. The systematic review is "[...] a well planned review to answer specific research questions using a systematic and explicit methodology to identify, select, and critically evaluate results of the studies included in the literature review" (Rother, 2007, p. v). The systematic review uses this structure to avoid slant - tendentiousness - in each one of its parts. In contrast to the traditional or narrative review, systematic reviews use a more rigorous, well defined approach to review the literature in a specific area (Cronin et al., 2008).

The main objective of an author when carrying out a literature review is to bring the reader up to date on the literature regarding a certain topic and, thus, form a basis for another objective, as well as giving the justification for future research in the area (Cronin et al., 2008). The systematic review of the literature has been employed to offer a critical view of current understanding of the research topic being studied (Araújo et al., 2017).

Following this, we present topics on how data collection was carried out, followed by how the selected articles were analyzed.

\subsection{Data collection and analysis}

Having defined the objective and the database (Scopus and Web of Science) to be used, the next step was the collection of the material to be analyzed. In order to identify articles that dealt with Social Capital and KM in team contexts, the following key words were used in the research, searching for the following terms 'abstract' and 'keywords': ("agile" OR "scrum" OR "team") AND ("knowledge management" OR "knowledge sharing" OR "knowledge creation" OR "knowledge storage" OR "knowledge use") AND ("social capital"). In addition, only journals were considered as a research source and likewise, articles as documents. This article selection process was carried out in April, 2017 and there was no delimitation as regards the year of publication of the articles.

Figure 1 depicts the data collection process. At first, the search resulted in 47 articles from Scopus database and 31 from Web of Science database. Removing papers that were common to both databases, 69 papers were left. These 69 were analyzed through the reading of the abstracts and classified as pertinent to the scope of the research or not. The criteria to verify the pertinence to the scope of the research used by the authors in this first selection process were as follows:

1. The identification in the article of the use of the Social Capital theory and;

2. The key-words associated with $\mathrm{KM}$.

In this analysis, twenty three articles were discarded for not being pertinent to the scope of the research, leaving forty six articles. A second selection process was carried out to analyze the content of the articles as a whole, mainly those where it was not clear from reading the abstract whether the article was pertinent to the scope of the 
research. After this reading, thrirtheen articles were discarded, resulting in thirty three articles to be analyzed in this research.

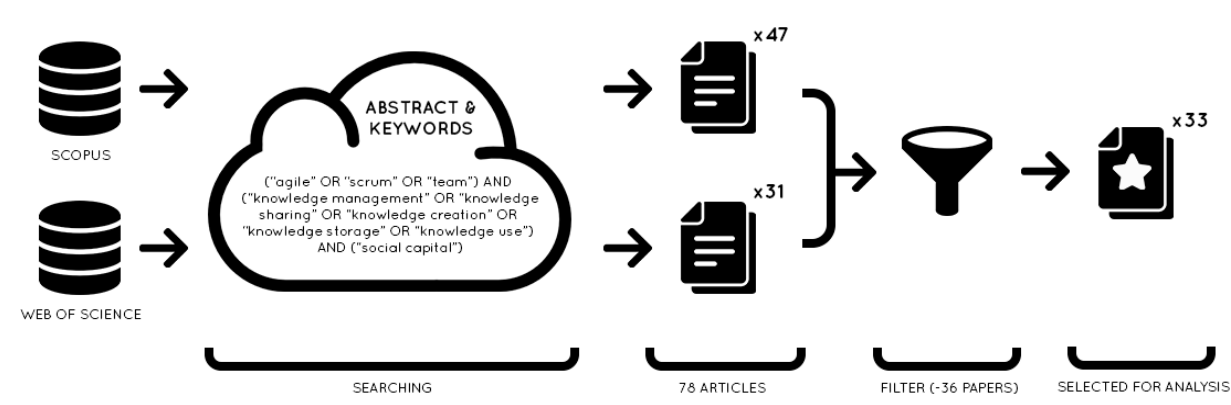

Figure 1. Data collection process.

For the analysis of the articles, a schedule was drawn up with the main aspects to be observed in each one of the articles, which were classified in four groups, as follows: reference; method; concepts, models and theories; and objectives and results found.

The reference contains the name of the article in which the study was published, the year of publication and also the number of citations of the same. The method concerns the type of research carried out, that is, theoretical or empirical, the approach used - quantitative or qualitative - and the sample characteristics, such as type of industry and teams studied, and the continent where the data was collected. The concepts, models and theories, for their part, include the research theoretical lens and the main concepts the authors used on which to base the study. Finally, the objectives and results include content analysis of the objectives and results of the thirty three articles studied.

As previously mentioned, after the construction of the data collection instrument, the collection of data in the articles began, according to the variables defined for each one of the groups. The analysis was based on a spreadsheet containing columns that identify the research (information exported from the Scopus database), and columns referring to the variables (created by the authors), with these being filled in as the articles were read. The filling in of the columns was carried out by means of copying and pasting of extracts from the articles that dealt with the construct observed, for later analysis. Data collection was carried out by more than one author, with the reading initially done together, along with the codification of the three articles on the spreadsheet, with a view to calibrate the method, thus seeking to guarantee reliability on codification.

After the completion of the spreadsheet, content analysis was adopted following Bardin's (2011) principles of semantic categorization, considering the significance of the theme. Eight categories of objectives a posteriori were created, along with and an a posteriori category called "Knowledge Sharing" in which terms with the same semantic meaning were grouped, as for example: exchanging knowledge, combining knowledge, flow of knowledge. The eight categories of objectives were later mapped in relation to the five potential benefits of $\mathrm{KM}$ following the same criteria of semantic categorization in Bardin (2011), for example, the objectives 'better performance' and 'project success' objectives were categorized as 'Improving performance'. 


\section{Analysis of the articles}

This section presents the descriptive analysis of the articles, structures according to the four groups: reference, method, concepts, models and theories; and objectives and results.

\subsection{Reference analysis}

Table 1 lists the journals in which the articles were published and then the number of articles per journal. Publication regarding this topic of study is well distributed among the journals. These 29 journals are classified into more than one area of knowledge; the areas where the greatest number is classified are: Business, Management and Accounting - 18 journals; Computer Science -13 journals; Social Science -8 journals; Psychology -6 journals. This shows that the theme in question is of interest in different areas of knowledge. This confirms Ragab \& Arisha (2013), when they say that KM is researched from different domains, with an overlapping of the areas.

Table 1. Number of articles analyzed per journal.

\begin{tabular}{|c|c|}
\hline Journal & Quantity \\
\hline Behavior and Information Technology & 1 \\
\hline Computers in Human Behavior & 1 \\
\hline Decision Sciences & 1 \\
\hline Group and Organization Management & 1 \\
\hline Human Relations & 1 \\
\hline Information \& Management & 1 \\
\hline IEEE Transactions on Engineering Management & 1 \\
\hline Industrial Management and Data Systems & 1 \\
\hline Information and Software Technology & 1 \\
\hline Information Systems Research & 1 \\
\hline Information Technology and Management & 1 \\
\hline International Journal of Distance Education Technologies & 1 \\
\hline International Journal of Information Management & 1 \\
\hline International Journal of Manpower & 1 \\
\hline International Journal of Project Management & 2 \\
\hline Journal of Knowledge Management & 2 \\
\hline Journal of Information Science & 2 \\
\hline Journal of Management Information Systems & 1 \\
\hline Jurnal Pengurusan & 1 \\
\hline Knowledge Management Research \& Practice & 1 \\
\hline Learning Organization & 2 \\
\hline Managing Knowledge For Global And Collaborative Innovations & 1 \\
\hline MIS Quarterly: Management Information Systems & 1 \\
\hline Project Management Journal & 1 \\
\hline Personnel Review & 1 \\
\hline Social Behavior and Personality & 1 \\
\hline Technological Forecasting and Social Change & 1 \\
\hline $\begin{array}{l}\text { The University of Michigan and in alliance with the Society of Human Resources } \\
\text { Management }\end{array}$ & 1 \\
\hline Universal Business Review & 1 \\
\hline
\end{tabular}


Figure 2 shows the distribution of the articles over time. As previously mentioned, there was no delimitation as to the year of publication in the database search. Observing this figure, we can identify that the publications integrating the subjects of $\mathrm{KM}$, Social Capital and Teams began in the first half of the 2000s, with an increase in publications in the current decade.

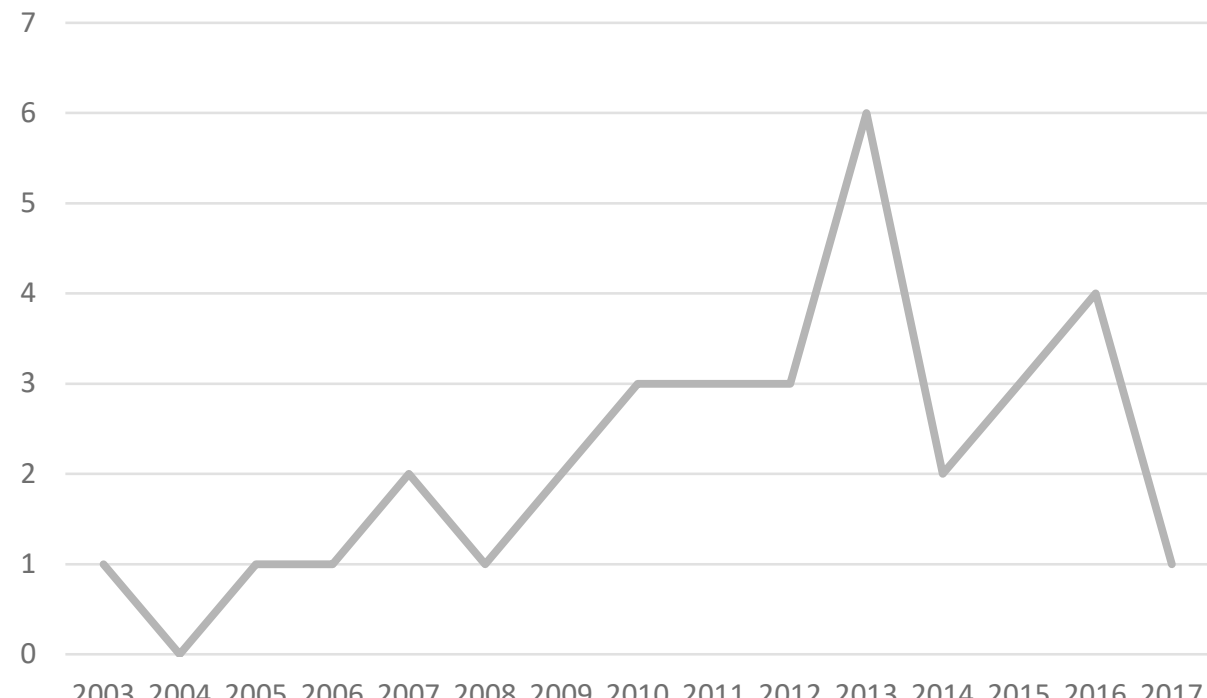

Figure 2. Publications over the years.

In 2017 there was just one publication, probably due to the fact that this report was carried out in the month of April of the same year. Regarding the number of times the articles were cited (Figure 3), $21 \%$ of the articles were cited more than 100 times each and $42 \%$ had between 11 and 50 citations. On the other hand, 10 articles had a low number of citations (up to 10), which for the most part can be attributed to the year of publication of the articles being more recent.

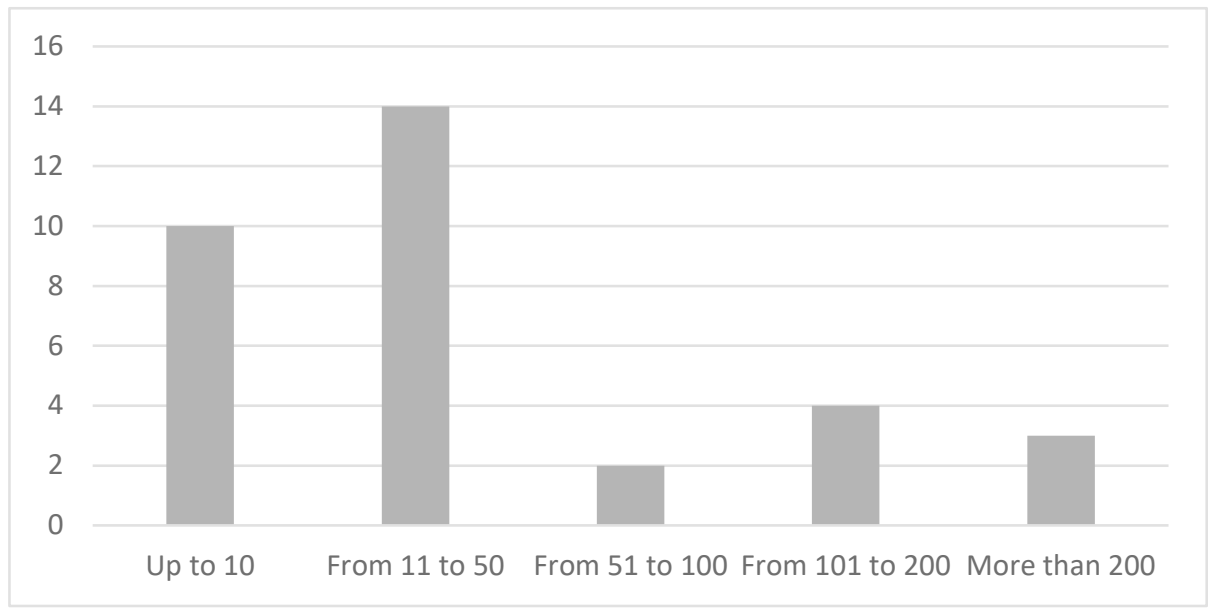

Figure 3. Number of articles vs citations. 
The following section presents the analysis of the research methods used in the articles selected for this systematic literature review.

\subsection{Method analysis}

With relation to the type of research carried out on the thirty three articles studied, thirty presented empirical research, and three theoretical research. Among the articles that carried out empirical research, twenty six applied quantitative methods, two qualitative and two applied mixed methods. Figure 4 details the methods used in the empirical research.

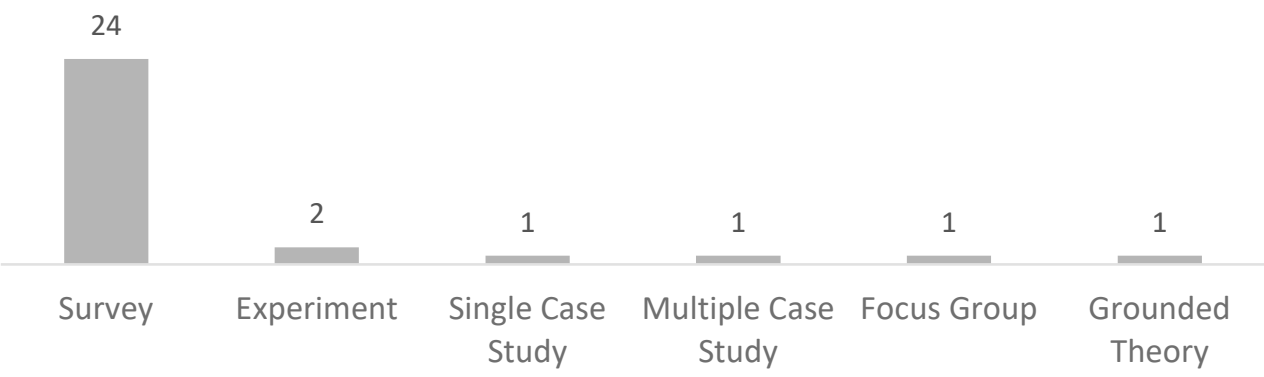

Figure 4. Method used in empirical research vs. Number of Articles.

According to Figure 4, the concentration of quantitative research using the Survey method can be justified by the objectives of the researches, for in their majority they seek to prove hypotheses in a determined sample.

The information referring to the field of action of the organizations where the data were collected is described in Table 2. A concentration of research in the IT industry can be observed, more specifically software development. The authors attribute this concentration to fact that $\mathrm{KM}$ is still more spread in companies with intensive knowledge, as is the case with the IT area. In second place, industry/activity 'Mixed' can be observed, which is characterized by applied research in more than one type of industry or activity, often not mentioned in the research.

Table 2. Industries or activities of the organizations.

\begin{tabular}{lcc}
\hline \multicolumn{1}{c}{ Industry/Activity } & Quantity & Percentage (\%) \\
\hline Information Technology & 11 & $37 \%$ \\
\hline Mixed & 6 & $20 \%$ \\
\hline Students & 3 & $10 \%$ \\
\hline Product Development & 2 & $7 \%$ \\
\hline Engineering/Construction & 2 & $7 \%$ \\
\hline Consulting & 1 & $3 \%$ \\
\hline Hospitals & 1 & $3 \%$ \\
\hline Turism & 1 & $3 \%$ \\
\hline Banking & 1 & $3 \%$ \\
\hline Not Mentioned & 2 & $\mathbf{7 \%}$ \\
\hline Total & $\mathbf{3 0}$ & $\mathbf{1 0 0 \%}$ \\
\hline
\end{tabular}


With the objective of analyzing KM from a perspective of Social Capital inside teams, the empirical research was categorized according to the geographical location of the team's members. The team members worked physically close to each other on just one article. Geographically distributed teams were part of eleven empirical research groups. The other eighteen papers did not mention the location of the teams that were being studied. With an ever globalized economy, distribution of teams in different time periods, in different cities, countries and even continents is becoming more common - in the IT industry this distribution commonly occurs. People spread in different geographical locations possess different social networks, and this can cause an impact on knowledge sharing.

Table 3 presents geographical information according to the continent where data collection of the thirty papers of empirical research was carried out. One can observe a predominance in the application of research in Asian countries. This could be a reflection of three situations: 1 - Asia is standing out scientifically with the increase of research related to the most diverse areas of knowledge; 2 - the fact that the research was applied for the most part in the IT industry and in the context of software outsourcing, which has a concentration in countries in Southeast Asia; 3 - one of the most cited authors in KM, Ikujiro Nonaka, is from Asia.

Table 3. The Continent where the empirical research was applied.

\begin{tabular}{cc}
\hline Continent & Number of Researches \\
\hline Asia & 18 \\
\hline Europe & 8 \\
\hline North America & 3 \\
\hline South America & 1 \\
\hline Oceania & 1 \\
\hline Not mentioned & 3 \\
\hline
\end{tabular}

In the following section, we present the analysis and discussion relative to the concepts, models and theories that were used in the thirty three articles selected.

\subsection{Analysis of the concepts, models and theories}

With regard to the use of the three dimensions of Social Capital, it can be observed that several studies mention more than one dimension, but not all. The Structural dimension was the most used in the articles analyzed, cited in 23 articles, that is, $70 \%$ of the articles selected. The second most used dimension was relational, mentioned in 22 articles, representing $67 \%$. And, finally, the Cognitive dimension, present in 18 articles, representing $55 \%$ of the articles analyzed. The three dimensions were used together in 11 articles and the isolated use of one dimension was of Structural, in 2 articles. A total of three articles do not mention any of the dimensions, merely referring to the theory as a whole. Noticing that the Structural dimension is used more than the other dimensions, it is believed that this is related to the fact that knowledge sharing is the most used of KM processes. Sharing demands social interactions (Gonzalez \& Martins, 2017; Nonaka, 1994), which can be stimulated by connections and ties inherent in the Structural dimension, thus serving as a conducting channel of knowledge. 
In the research analyzed, consensus was not identified in relation to the Social Capital dimensions that have the most impact on KM. Van Dijk et al. (2016) mention the Structural dimension as significant for the process of knowledge sharing and the Cognitive dimension as predictor of the quality of knowledge shared. In turn, Bakker et al. (2006) emphasizes the facet of identification contained in the Relational dimension as having the greatest effect on knowledge sharing, as opposed to trust, which was the hypothesis tested in the research.

Different terminologies to refer to the four processes of KM - create, store, share, use - were identified. So as to facilitate understanding, the following terms were grouped to the process of "Shared Kowledge", due to the way in which they were utilized: collaborating on knowledge, exchanging knowledge, combining knowledge, transferring knowledge and knowledge flow. Table 4 presents the list of Knowledge Management processes that were most used in the articles studied.

Table 4. Use of Knowledge Management processes in the articles.

\begin{tabular}{cc}
\hline Process & $\mathbf{N}^{\circ}$ of articles \\
\hline Sharing & 28 \\
\hline Creating & 4 \\
\hline Storing & 0 \\
\hline Using & 0
\end{tabular}

The more frequent use of the "Sharing" process in relation to the other KM processes matches the literature, which emphasizes knowledge sharing as a generator of new ideas, considering it as one of the most important Knowledge Management processes (Oliveira et al., 2015). The storing process can also be seen as part of creation or sharing, which could explain the fact that no article analyzed used this process specifically. The process of using knowledge is what brings value to KM. However, this process is the most difficult to be isolated, which could be an explanation for it not having been identified in then articles analyzed. Among the thirty three papers analyzed, there were four papers that have not mentioned any specific process, focusing on $\mathrm{KM}$ itself.

Analyzing the research with relation to the adoption of models and theories, it can be verified that as well as the theory of Social Capital (which was used in the thirty three articles), ten other organizational models and theories were used, as detailed in Table 5.

Observing the description of the theories and models presented in Table 5, a connection between these and the theory of Social Capital can be seen concerning relations between individuals, as in Social Network and Social Exchange Theory. The other theories are related, by means of knowledge, to the discipline of KM. The Social Mental Model suggests a link both with the theory of Social Capital and KM, for it involves relations and knowledge. According to Xavier et al. (2012), the theory of Social Capital and Social Exchange Theory are among the most used theories in research involving $\mathrm{KM}$. 
Table 5. Models and Theories identified.

\begin{tabular}{|c|c|c|}
\hline Name of Theory or Model & Description & Reference \\
\hline Social Network Theory & $\begin{array}{l}\text { Studies social relations in } \\
\text { terms of nodes (actors) and } \\
\text { ties (relations between actors). }\end{array}$ & $\begin{array}{l}\text { Association for Information } \\
\text { Systems (AIS, 2017) }\end{array}$ \\
\hline Social Exchange Theory & $\begin{array}{l}\text { Sees the relation of exchange } \\
\text { between actors as actions } \\
\text { conditioned to reactions of } \\
\text { recognition }\end{array}$ & $\begin{array}{l}\text { Association for Information } \\
\text { Systems (AIS, 2017) }\end{array}$ \\
\hline Intellectual Capital Theory & $\begin{array}{l}\text { Refers to knowledge and the } \\
\text { ability of a social collective to } \\
\text { gain it. }\end{array}$ & $\begin{array}{c}\text { Nahapiet \& Ghoshal } \\
(1998)\end{array}$ \\
\hline Social Mental Model & $\begin{array}{l}\text { Common style of thinking } \\
\text { developed when individuals } \\
\text { carry out similar tasks in a } \\
\text { cohesive way. }\end{array}$ & Xiang et al. 2013 \\
\hline $\begin{array}{l}\text { Intellectual Capital Based } \\
\text { View }\end{array}$ & $\begin{array}{l}\text { Proposes and tests intellectual } \\
\text { capital based on view of the } \\
\text { company. }\end{array}$ & Reed et al. (2006) \\
\hline Knowledge Base View & $\begin{array}{l}\text { Considers knowledge as the } \\
\text { most strategic and significant } \\
\text { resource in the company. }\end{array}$ & $\begin{array}{l}\text { Association for Information } \\
\text { Systems (AIS, 2017) }\end{array}$ \\
\hline $\begin{array}{l}\text { Organizational Knowledge } \\
\text { Creation Theory }\end{array}$ & $\begin{array}{l}\text { Organizational knowledge is } \\
\text { created through continuous } \\
\text { dialogue between tacit and } \\
\text { explicit knowledge. }\end{array}$ & $\begin{array}{l}\text { Association for Information } \\
\text { Systems (AIS, 2017) }\end{array}$ \\
\hline $\begin{array}{l}\text { Social Information } \\
\text { Processing theory }\end{array}$ & $\begin{array}{l}\text { Suggests that individuals } \\
\text { express suitable attitudes and } \\
\text { behaviors based on } \\
\text { observation of social cues and } \\
\text { environments. }\end{array}$ & Salancik \& Pfeffer (1978) \\
\hline System Theory & $\begin{array}{l}\text { Recognizes the individual as } \\
\text { an element within the context } \\
\text { of his or her team }\end{array}$ & Hoegl et al. (2003) \\
\hline Social Interaction Theory & $\begin{array}{l}\text { Suggests that, if a team has a } \\
\text { high level of network } \\
\text { preference, then individuals } \\
\text { will also perceive a strong } \\
\text { need to build networks. }\end{array}$ & Bandura (1986) \\
\hline
\end{tabular}

\subsection{Analysis of the objectives and results of the articles}

Organizations with intensive use of knowledge are more and more common. The globalized economy and the massive use of technologies transform knowledge into an even more valuable and strategic component, which makes the management of this knowledge essential inside organizations. The motivation of organizations in carrying out $\mathrm{KM}$ is to promote improvements in business performance, and for this there needs to be efficient KM (Hansen et al., 1999; Mills \& Smith, 2011).

With the aim of offering a critical view of the current understanding of the research topic, a content analysis of the results of the 33 papers that make up this literature review was carried out, in which we sought to trace a line connecting the research aim with the benefits of effective KM. According to the literature (Davenport \& Prusak, 1998; Lee, 2001; Karkoulian et al., 2010), these benefits are: organizational learning, performance improvement, continuous process' improvement, innovation and the 
generation of competitive advantage. Table 6 shows the relation between the research objectives and the benefits presented in KM literature. The first column contains the objective categorized by the authors of this study, the second column shows the number of studies that have this objective and the third column represents the association of the objective with one of the benefits presented by KM.

Table 6. Relation between the objectives of the articles and the benefit pointed out in the literature.

\begin{tabular}{lcc}
\hline \multicolumn{1}{c}{ Objective } & $\begin{array}{c}\text { Quantity of } \\
\text { Empirical Articles }\end{array}$ & Benefit \\
\hline $\begin{array}{l}\text { Improvement in Performance } \\
\text { Project Success }\end{array}$ & 12 & $\begin{array}{c}\text { Performance Improvement } \\
\text { Performance Improvement }\end{array}$ \\
\hline $\begin{array}{l}\text { Knowledge Sharing } \\
\text { Learning }\end{array}$ & 1 & $\begin{array}{c}\text { Organizational Learning } \\
\text { Organizational Learning }\end{array}$ \\
\hline Improve Knowledge Management & 8 & $\begin{array}{c}\text { Continuous Process' } \\
\text { Improvement }\end{array}$ \\
\hline Efficency at Work & 2 & $\begin{array}{c}\text { Continuous Process' } \\
\text { Improvement }\end{array}$ \\
\hline $\begin{array}{l}\text { Enhancement on Coordination } \\
\text { Continuous Improvement }\end{array}$ & 1 & $\begin{array}{c}\text { Continuous Process' } \\
\text { Improvement } \\
\text { Innovation }\end{array}$ \\
& 1 & $\begin{array}{c}\text { Continuous Process' } \\
\text { Improvement } \\
\text { Innovation }\end{array}$ \\
\hline
\end{tabular}

Analysis of Table 6 allows us to identify a predominance of research that aims to study performance. This phenomenon, along with the fact that just one study is related to Innovation, can be interpreted as a possible consequence of the predominant activity of the samples being software outsourcing, which traditionally requires good productivity and not necessarily innovation. Using the information from Table 6 , the percentage distribution of research already mapped in relation to respective benefits can be seen in Figure 5.

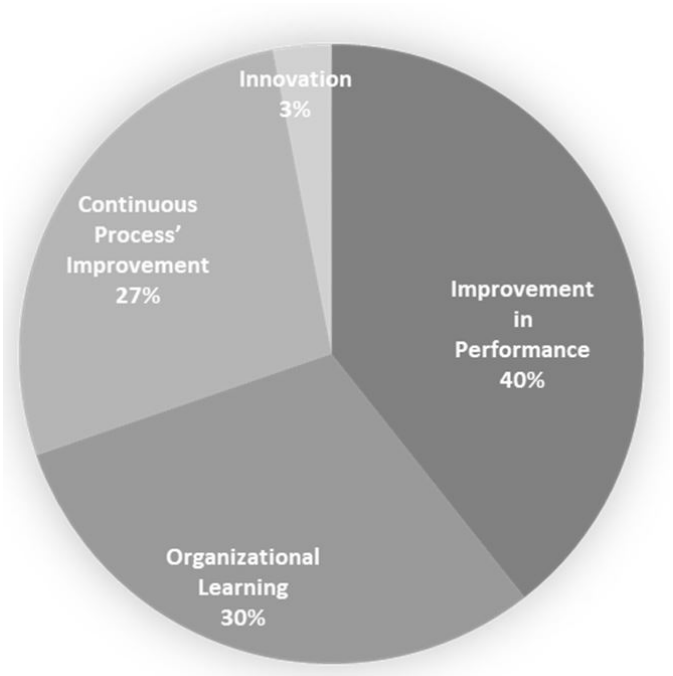

Figure 5. Research objectives mapped in relation to the benefit of effective KM. 
Figure 5 shows more clearly that the benefit of competitive advantage was not mentioned as an objective of any of the research studied. The authors attribute to this fact the same reason mentioned in the previous paragraph to explain the question of innovation, that is, the predominant context of software outsourcing, where factors such as performance, learning and improvement in processes are more relevant. Another possible interpretation is that achieving other benefits individually can also result in organizations obtaining competitive advantages, that is, continuous improvement in processes, the obtaining of organizational learning and improved productivity can suggest some competitive advantage in relation to rival organizations.

With relation to the results achieved by the articles studied, among those that aimed to analyze the question of performance jointly with Social Capital, some results stand out, such as the research by Robert et al. (2008), which suggests the influence of the three dimensions of Social Capital in the integration of knowledge and consequent improvement in performance. In addition, the research by Henttonen et al. (2013) emphasizes the structural properties of the teams (Structural dimension of Social Capital) and the relationship with productivity. Research by Lee et al. (2015) concludes that the Social Capital of the team influences the sharing of knowledge and this contributes indirectly to an improvement in performance.

Research by Šmite et al. (2017) and Gao et al. (2016) stresses the importance of network ties as an essential role to feed the social capital of organizations and through this generate and share knowledge. The role of leadership as a motivator and facilitator of knowledge sharing appears significant in the research, with the addition of explicit incentive in order to have exchange of knowledge - especially tacit knowledge - among team members (Zhang \& Cheng, 2015; Hu \& Randel, 2014; Martín-de-Castro \& Montoro-Sánchez, 2013). Another result presented was related to the density and size of the network of relationships. Research by Yu et al. (2013) suggests that this topic should be dealt with more deeply in future research, as well as tested empirically through comparison with different sizes and network densities so that there can be balance between cohesion inside a team and received knowledge from external sources.

In the research applied to distributed teams, as well as the significant role of relationships to generate knowledge exchange and improved team performance, research by Lee et al. (2015) and Šmite et al. (2017) emphasizes as a practical contribution the need to make available training and technological tools suitable for communication to minimize the effects of distance and contribute to a good work atmosphere.

Among the limitations of the research analyzed, the sample limitation regarding variation stands out - that is, the sample with respondents from just one type of industry and country - the possibility of perspective with relation to the use of just one collection method - since the majority used survey - and transversal data collection (Lin, 2011; Xiang et al., 2013; Wu et al., 2015). As opportunities for future research related to the method used, as well as the increase in the sample to other industries and countries, the use of triangulation of collection methods and longitudinal data collection is cited. In relation to the content dealt with, the following opportunities for research were identified:

- Focus on the leadership behavior;

- Measuring of the impact of innovation;

- Size and density of relationship networks; 
- Use of social media as a channel for knowledge sharing;

- Different combinations of Social Capital dimensions;

- Impact of cultural questions;

- Impact of the human factor.

The authors' attention is drawn to the fact that just one of the studies analyzed referred to teams that worked with Agile methods. It was not possible to identify if the other research simply did not make any reference (but the method was used by the teams) or the method in fact was not used. The authors point out this gap as an opportunity for future research.

The next section focuses on the discussion of the research based on the information and analysis presented in section 4 .

\section{Discussion}

Section 4 presented information referring to the constructs observed as well as analysis carried out regarding this information. Adding the analysis, this section shows a scheme (Figure 6) which quantifies the results of the analysis of the research concerning the theory of Social Capital and KM with a general discussion of the study.

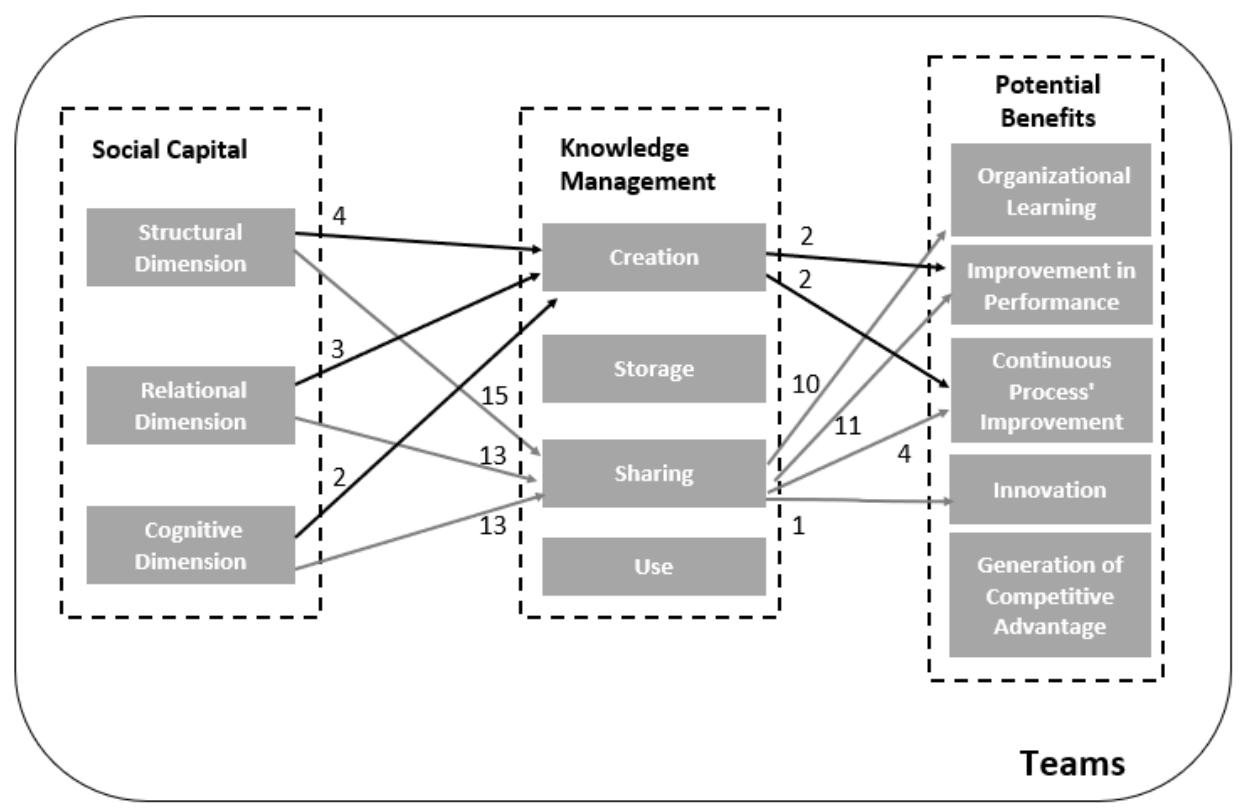

Figure 6. Quantitative result of the research in relation to the concepts.

Figure 6 offers a quantitative view after the analysis of the articles. The numbers next to the arrows indicate the number of articles that mention the concept, for example 13 articles that use the Cognitive dimension utilize the process of sharing, and 11 articles that study sharing had their objective linked to the potential benefit of KM referring to "Improvement in Performance". As already shown, the process of Knowledge Sharing was the most used in the research studied, with the objective of the research that used KS being 'Improvement in performance' or 'Organizational Learning'. Although the facets of the dimensions of Social Capital were not the focus 
of the analysis, the facets of 'Network Ties' and 'Network Configuration', belonging to the Structural dimension and the facet of 'Identification', belonging to the Relational dimension, stand out as being frequently mentioned. The authors suggest that the most frequent use of these facets can be related to the team context.

Also in relation to Figure 6, the potential benefit of "Innovation" stands out as having been mentioned as an objective in just one study (Table 6). As already shown, the authors suggest that the fact that "Innovation" and "Competitive Advantage" had been minimally mentioned can be attributed to the type of industry where the research was applied and to the context of software outsourcing (predominant context in the research applied in the IT industry), seeing that these industries work in their majority with service provision, with good performance their main objective.

With relation to the context of the research studied, the predominance of data collection in the Asian continent can be noted, and it is believed that it can be related to the growing academic production there. Asia has been distinguishing itself scientifically with the increase in research related to the most diverse areas of knowledge. Concerning the journals in which the 33 articles were published, a distribution of the publications can be noted, with the greatest recurrence being articles published in the same journal. It is understood that this can be a reflection of the fact that $\mathrm{KM}$ is a transversal theme over diverse industries, with the result that journals from different areas deal with the theme.

As mentioned previously, the authors are struck by the minimal reference in the research to the use of Agile Methods on the part of the teams. In the organizational context, agility involves identifying and responding quickly to changes and being faster in the delivery of results. One of the ways of obtaining this agility is through the utilization of this work method. Focus on teams that use agile methods to develop tasks is suggested as an opportunity for future research in KM and Social Capital. These methods make intensive use of tacit knowledge to the detriment of explicit knowledge and have a format of relationship that is also differentiated, generating a need for the use of Social Capital and KM, with a view to obtaining the fundamental benefits in the literature.

Finally, with the analysis carried out it was possible to identify that the majority of the studies have the relation between the two main topics with the objective of improving performance and sharing knowledge. Both objectives have an important practical contribution to the organizations, since discussions on performance and KM are recurrent among managers and, as pointed out by Oliveira et al. (2015), the sharing of knowledge is seen as a generator of new ideas. The joint research on Social Capital with Knowledge Sharing is significant, for, as already indicated by Cohen \& Levinthal (2000), the skill at recognizing new knowledge and assimilating it is essential for organizational learning and for innovation. Furthermore, the socialization that takes place through network ties is the key in the construction of knowledge; in agreement with Nonaka \& Takeuchi (1995) and Walker \& Christenson (2005), as people interact and share, they absorb and apply this shared knowledge, generating new knowledge.

\section{Conclusion}

This work offers as a main theoretical contribution an analysis of the state of the discipline of $\mathrm{KM}$ in a team context, analyzed in the light of Social Capital theory. The relation between these two topics is relatively new, found in articles from 2003 onwards, and have intensified in the past five years. In addition to this, the analysis 
carried out in this article could serve as a springboard for more studies on this topic, starting from the identification of theoretical gaps.

With relation to management implications, through analysis it was identified that $\mathrm{KM}$ and Social Capital can be used jointly with the aim of improving performance and knowledge sharing in organizations. In addition, since the majority of the studies are empirical, professionals such as team and project managers can identify more easily ways of applying the concepts and contexts studied.

Concerning the limitations of the present research, the small number (just one) of studies whose teams were mentioned as users of agile methods make an analysis of this aspect impossible. It is suggested as an opportunity for future research that the words used in the search of the context of agile methods be extended beyond agile and scrum.

\section{Acknowledgements}

We are gratefully acknowledge financial support from CAPES and CNPq (Brazil) and FCT (Portugal), national funding through research grant UIDB/04521/2020.

\section{References}

Alavi, M., \& Leidner, D. E. (2001). Knowledge management and knowledge management systems: conceptual foundations and research issues. Management Information Systems Quarterly, 25(1), 107-136. http://dx.doi.org/10.2307/3250961.

Alguezaui, S., \& Filieri, R. (2010). Investigating the role of social capital in innovation: sparse versus dense network. Journal of Knowledge Management, 14(6), 891-909. http://dx.doi.org/10.1108/13673271011084925.

Anand, A., \& Singh, M. D. (2011). Understanding knowledge management. International Journal of Engineering Science and Technology, 3(2), 926-939.

Araújo, M. C. B., Alencar, L. H., \& Miranda Mota, C. M. (2017). Project procurement management: a structured literature review. International Journal of Project Management, 35(3), 353-377. http://dx.doi.org/10.1016/j.jproman.2017.01.008.

Association for Information Systems - AIS. (2017). Methods and theories. Atlanta: AIS. Retrieved in 2017, December 7, from https://is.theorizeit.org/wiki/Main_Page

Bakker, M., Leenders, R. T. A., Gabbay, S. M., Kratzer, J., \& Van Engelen, J. M. (2006). Is trust really social capital? Knowledge sharing in product development projects. The Learning Organization, 13(6), 594-605. http://dx.doi.org/10.1108/09696470610705479.

Bandura, A. (1986). Social foundations of thought and action: a social cognitive view. New Haven: Yale University Press.

Bardin, L. (2011). Análise de conteúdo. São Paulo: Edições 70.

Bourdieu, P. (1986). The forms of capital. In J. G. Richardson (Ed.), Handbook of theory and research for the sociology of education (pp. 241-258). New York: Greenwood Press.

Carvalho, N., \& Gomes, I. (2017). Knowledge sharing between enterprises of the same group. International Journal of Knowledge Management, 13(1), 34-52. http://dx.doi.org/10.4018/IJKM.2017010103.

Cohen, W. M., \& Levinthal, D. A. (2000). Absorptive capacity: a new perspective on learning and innovation. In R. L. Cross Jr. \& S. B. Israelit (Eds.), Strategic learning in a knowledge economy (pp. 39-67). Cambridge: Elsevier. http://dx.doi.org/10.1016/B978-0-7506-72238.50005-8. 
Coleman, J. S. (1994). Foundations of social theory. Cambridge: Harvard University Press.

Conboy, K. (2009). Agility from first principles: reconstructing the concept of agility in information systems development. Information Systems Research, 20(3), 329-354. http://dx.doi.org/10.1287/isre.1090.0236.

Cronin, P., Ryan, F., \& Coughlan, M. (2008). Undertaking a literature review: a step-by-step approach. British Journal of Nursing (Mark Allen Publishing), 17(1), 38-43. http://dx.doi.org/10.12968/bjon.2008.17.1.28059. PMid:18399395.

Davenport, T. H., \& Prusak, L. (1998). Working knowledge: how organizations manage what they know. Boston: Harvard Business Press.

Devine, D. J., Clayton, L. D., Philips, J. L., Dunford, B. B., \& Melner, S. B. (1999). Teams in organizations: prevalence, characteristics, and effectiveness. Small Group Research, 30(6), 678-711. http://dx.doi.org/10.1177/104649649903000602.

Filieri, R., \& Alguezaui, S. (2014). Structural social capital and innovation. Is knowledge transfer the missing link? Journal of Knowledge Management, 18(4), 728-757. http://dx.doi.org/10.1108/JKM-08-2013-0329.

Gao, S., Guo, Y., Chen, J., \& Li, L. (2016). Factors affecting the performance of knowledge collaboration in virtual team based on capital appreciation. Information Technology and Management, 17(2), 119-131. http://dx.doi.org/10.1007/s10799-015-0248-y.

Gonzalez, R. V. D., \& Martins, M. F. (2017). Knowledge management process: a theoreticalconceptual research. Gestão \& Produção, 24(2), 248-265. http://dx.doi.org/10.1590/0104530x0893-15.

Hambley, L. A., O'Neill, T. A., \& Kline, T. J. (2007). Virtual team leadership: the effects of leadership style and communication medium on team interaction styles and outcomes. Organizational Behavior and Human Decision Processes, 103(1), 1-20. http://dx.doi.org/10.1016/j.obhdp.2006.09.004.

Hansen, M. T., Nohria, N., \& Tierney, T. (1999). What's your strategy for managing knowledge. In J. A. Woods \& J. Cortada (Eds.), The knowledge management yearbook 2000-2001 (pp. 1-10). Hoboken: Taylor \& Francis.

Henttonen, K., Janhonen, M., \& Johanson, J. E. (2013). Internal social networks in work teams: structure, knowledge sharing and performance. International Journal of Manpower, 34(6), 616-634. http://dx.doi.org/10.1108/IJM-06-2013-0148.

Hoegl, M., Parboteeah, K. P., \& Munson, C. L. (2003). Team-level antecedents of individuals' knowledge networks. Decision Sciences, 34(4), 741-770. http://dx.doi.org/10.1111/j.15405414.2003.02344.x.

Hu, L., \& Randel, A. E. (2014). Knowledge sharing in teams: social capital, extrinsic incentives, and team innovation. Group \& Organization Management, 39(2), 213-243. http://dx.doi.org/10.1177/1059601114520969.

Isa, R. M., Abdullah, N. L., \& Senik, Z. C. (2010). Social capital dimensions for tacit knowledge sharing: exploring the indicators. Jurnal Pengurusan, 30, 75-91. http://dx.doi.org/10.17576/pengurusan-2010-30-06.

Karkoulian, S., Harake, N. A., \& Messarra, L. C. (2010). Correlates of organizational commitment and knowledge sharing via emotional intelligence: an empirical investigation. Business Review, 15(1), 89-96.

Keyton, J., \& Beck, S. J. (2008). Team attributes, processes, and values: a pedagogical framework. Business Communication Quarterly, 71(4), 488-504. http://dx.doi.org/10.1177/1080569908325863.

Lee, J. N. (2001). The impact of knowledge sharing, organizational capability and partnership quality on IS outsourcing success. Information \& Management, 38(5), 323-335. http://dx.doi.org/10.1016/S0378-7206(00)00074-4. 
Lee, S., Park, J. G., \& Lee, J. (2015). Explaining knowledge sharing with social capital theory in information systems development projects. Industrial Management \& Data Systems, 115(5), 883-900. http://dx.doi.org/10.1108/IMDS-01-2015-0017.

Lin, C. P. (2011). Modeling job effectiveness and its antecedents from a social capital perspective: a survey of virtual teams within business organizations. Computers in Human Behavior, 27(2), 915-923. http://dx.doi.org/10.1016/j.chb.2010.11.017.

Martín-de-Castro, G., \& Montoro-Sánchez, Á. (2013). Exploring knowledge creation and transfer in the firm: context and leadership. Universia Business Review, (40), 126.

Mills, A. M., \& Smith, T. A. (2011). Knowledge management and organizational performance: a decomposed view. Journal of Knowledge Management, 15(1), 156-171. http://dx.doi.org/10.1108/13673271111108756.

Nahapiet, J., \& Ghoshal, S. (1998). Social capital, intellectual capital, and the organizational advantage. Academy of Management Review, 23(2), 242-266. http://dx.doi.org/10.5465/amr.1998.533225.

Nonaka, I. (1994). A dynamic theory of organizational knowledge creation. Organization Science, 5(1), 14-37. http://dx.doi.org/10.1287/orsc.5.1.14.

Nonaka, I., \& Konno, N. (1998). The concept of "ba": building a foundation for knowledge creation. California Management Review, 40(3), 40-54. http://dx.doi.org/10.2307/41165942.

Nonaka, I., \& Takeuchi, H. (1995). The knowledge-creating company: how Japanese companies create the dynamics of innovation. New York: Oxford University Press.

Oliveira, M., Curado, C. M., Maçada, A. C., \& Nodari, F. (2015). Using alternative scales to measure knowledge sharing behavior: are there any differences? Computers in Human Behavior, 44, 132-140. http://dx.doi.org/10.1016/j.chb.2014.11.042.

Polanyi, M. (1966). The tacit dimension. New York: Doubleday.

Ragab, M. A. F., \& Arisha, A. (2013). Knowledge management and measurement: a critical review. Journal of Knowledge Management, 17(6), 873-901. http://dx.doi.org/10.1108/JKM12-2012-0381.

Reed, K. K., Lubatkin, M., \& Srinivasan, N. (2006). Proposing and testing an intellectual capitalbased view of the firm. Journal of Management Studies, 43(4), 867-893. http://dx.doi.org/10.1111/j.1467-6486.2006.00614.x.

Robert, L. P., Jr., Dennis, A. R., \& Ahuja, M. K. (2008). Social capital and knowledge integration in digitally enabled teams. Information Systems Research, 19(3), 314-334. http://dx.doi.org/10.1287/isre.1080.0177.

Rother, E. T. (2007). Revisão sistemática $\times$ revisão narrativa. Acta Paulista de Enfermagem, 20(2), v-vi. http://dx.doi.org/10.1590/S0103-21002007000200001.

Ryan, S., \& O'Connor, R. V. (2013). Acquiring and sharing tacit knowledge in software development teams: an empirical study. Information and Software Technology, 55(9), 1614-1624. http://dx.doi.org/10.1016/j.infsof.2013.02.013.

Salancik, G. R., \& Pfeffer, J. (1978). A social information processing approach to job attitudes and task design. Administrative Science Quarterly, 23(2), 224-253. http://dx.doi.org/10.2307/2392563. PMid:10307892.

Serenko, A. (2013). Meta-analysis of scientometric research of knowledge management: discovering the identity of the discipline. Journal of Knowledge Management, 17(5), 773812. http://dx.doi.org/10.1108/JKM-05-2013-0166.

Serrador, P., \& Pinto, J. K. (2015). Does agile work? A quantitative analysis of agile project success. International Journal of Project Management, 33(5), 1040-1051. http://dx.doi.org/10.1016/j.ijproman.2015.01.006.

Sidhu, J. S., \& Volberda, H. W. (2011). Coordination of globally distributed teams: a coevolution perspective on offshoring. International Business Review, 20(3), 278-290. http://dx.doi.org/10.1016/j.ibusrev.2011.01.006. 
Šmite, D., Moe, N. B., Šāblis, A., \& Wohlin, C. (2017). Software teams and their knowledge networks in large-scale software development. Information and Software Technology, 86, 71-86. http://dx.doi.org/10.1016/j.infsof.2017.01.003.

Van Dijk, A., Hendriks, P., \& Romo-Leroux, I. (2016). Knowledge sharing and social capital in globally distributed execution. Journal of Knowledge Management, 20(2), 327-343. http://dx.doi.org/10.1108/JKM-07-2015-0268.

Walker, D. H., \& Christenson, D. (2005). Knowledge wisdom and networks: a project management centre of excellence example. The Learning Organization, 12(3), 275-291. http://dx.doi.org/10.1108/09696470510592520.

Wang, S., \& Noe, R. A. (2010). Knowledge sharing: a review and directions for future research. Human Resource Management Review, 20(2), 115-131. http://dx.doi.org/10.1016/j.hrmr.2009.10.001.

Wheelan, S. A., \& Hochberger, J. M. (1996). Validation studies of the group development questionnaire. Small Group Research, 27(1), 143-170. http://dx.doi.org/10.1177/1046496496271007.

Wu, D., Liao, Z., \& Dai, J. (2015). Knowledge heterogeneity and team knowledge sharing as moderated by internal social capital. Social Behavior and Personality, 43(3), 423-436. http://dx.doi.org/10.2224/sbp.2015.43.3.423.

Xavier, L. A., Oliveira, M., \& Teixeira, E. K. (2012). Teorias utilizadas nas investigações sobre gestão do conhecimento. Revista Ibérica de Sistemas e Tecnologias de Informação, (10), 1-17. http://dx.doi.org/10.4304/risti.10.1-18.

Xiang, C., Lu, Y., \& Gupta, S. (2013). Knowledge sharing in information system development teams: examining the impact of shared mental model from a social capital theory perspective. Behaviour \& Information Technology, 32(10), 1024-1040. http://dx.doi.org/10.1080/0144929X.2012.745901.

Yu, X., \& Petter, S. (2014). Understanding agile software development practices using shared mental models theory. Information and Software Technology, 56(8), 911-921. http://dx.doi.org/10.1016/j.infsof.2014.02.010.

Yu, Y., Hao, J. X., Dong, X. Y., \& Khalifa, M. (2013). A multilevel model for effects of social capital and knowledge sharing in knowledge-intensive work teams. International Journal of Information Management, 33(5), 780-790. http://dx.doi.org/10.1016/j.jijnfomgt.2013.05.005.

Zhang, L., \& Cheng, J. (2015). Effect of knowledge leadership on knowledge sharing in engineering project design teams: the role of social capital. Project Management Journal, 46(5), 111-124. http://dx.doi.org/10.1002/pmj.21525. 